\title{
En legeutdanning til pasientens beste - lærdommer av en syk ungdomstid
}

\author{
Medisinstudenter kan ofte søke mestring i en objektiverende og teknisk tilnærming til sykdom. Gjennom \\ egen alvorlig sykdom lærte jeg at pasienter trenger mer - de trenger leger som forstår mennesker.
}

Jeg ligger i sengen i sykehuskorridoren, har nettopp vært på min første MR-undersøkelse. Etter et halvt år med oppkast opptil 40 ganger hver dag er jeg lei. Livet er håpløst når kvalmestillende ikke hjelper, og alt er satt på vent. Jeg er 14 år og vil bare tilbake på skolen for å ha en vanlig ungdomstid.

$\AA$ komme på sykehus var en rystende hendelse som intensiverte min sykdomsopplevelse og gjorde den mer alvorlig. For legene var det ikke noe ekstraordinært i situasjonen - de var jo på sykehus hver dag. I legejobben kan lidelsesfylte og skjebneomveltende situasjoner fortone seg som rutine. Det kan skje dersom legen konsentrerer seg om det gjenkjennelige, det som ligner noe annet, som diagnosekategorien, og ikke utforsker det nye og særegne, nemlig hva situasjonen betyr i pasientens hverdag og livsprosjekt. Da speiles ikke pasientens opplevelse av intens sårbarhet. Legen som er blind for pasientens perspektiv, taper muligheten for å være til hjelp gjennom empati og refleksjon. At legen forstår og «ser» pasienten kan endre betydningen av fakta, uten at fakta i seg selv endres. I motsatt fall vil pasienten sitte igjen med en ordløs fortvilelse over at legen står uforstående og hjelpeløs overfor den eksistensielle sårbarheten som alltid følger alvorlig sykdom.

Selv om alt helsepersonell ønsker å yte godt, er det ikke alltid systemet gjør det lett. Standardiserte behandlingsopplegg kan usynliggjøre hjelpebehov ved at mennesket behandles ut fra sin diagnose, uten at det undersøkes hvordan sykdommen påvirker pasientens liv. Blant helsepersonell må det være en fagkultur der mennesket er spennende og viktig, ikke bare sykdommen og dens kjennetegn.

Den overskyggende diagnosejakten En lege kommer ut fra røntgenavdelingen. Hun ser med store, positive øyne på meg og min mor, som sitter ved siden av meg. «Jeg kan ikke gi noe fullstendig svar ennå, men vi så iallfall ikke noe tegn til kreft på bildene», sier hun optimistisk. Jeg presser frem et smil og takker, men sjelden har jeg vært mer skuffet. Å ha kreft ville vært bedre enn ikke å ha en diagnose.
Min lidelse ble større av ikke å få en diagnose, fordi det betydde å leve videre med uvisshet $\mathrm{i}$ et vaklende håp om å bli frisk. Jeg lærte at uten en diagnose kan behandlingsrekken stoppe. Leger må lære å hjelpe pasienter selv om ikke sykdommen har en klar behandling. Det kan de gjøre ved å bruke lege-pasient-forholdet til å endre sykdommens betydning for den syke. Der-

\section{«Leger må ta ansvar for à undersøke pasienters følelser»}

for må forståelse av hjelpepotensialet i legerollen sterkere inn i legefaget. Undervisning i biologi og sykdomslære må kombineres med innsikt $i$ at sykdom skader personers identitet, verdier og livsmål. Hvis ikke, kan legen låses i et diagnosefokusert tunnelsyn der mulighetene for å hjelpe pasienten til å leve med plagene, blir usynlige.

Pasienten må støttes i å takle livet mens diagnosejakten foregår - og når behandlingsmulighetene tar slutt. Det krever at legen er interessert i og trygg på egne og andres emosjoner. Læring som kan styrke slike egenskaper, blir i stor grad neglisjert gjennom legeutdanningen. Håndtering av emosjoner er viktig, slik at ikke legens private ubehag over å kjenne seg hjelpeløs kommer i veien for å være profesjonelt opptatt av å lindre den andres fortvilelse. Med sykdom følger tanker om død, det tapte i nåtiden og frykten for en uviss fremtid. Leger må ikke bidra til en mur av fortielse rundt slike følelser. De må kunne møte andres sårbarhet med trygghet på egen, slik at den fellesmenneskelige sårbarheten blir et redskap for å forstå pasienten. Medisinstudenter må derfor gjennom studiet lære å forstå seg selv og sin rolle for pasientene. Da kan de gi eksistensiell støtte og tilby en arena der tanker og bekymringer kan berøres - hvis pasienten vil.

\section{Mennesket bak sykdommen}

Det neste halve året kaster jeg på dårlige dager opp over 100 ganger. Etter nesten ett år med mat gjennom en nesesonde alle kan se $i$ ansiktet mitt, skal jeg endelig opereres slik at jeg kan få sondemat rett i tarmene. Noen dager etter operasjonen blir jeg dårlig utover natten. Om morgenen sender jeg en tekstmelding til min mor. «Kom», er alt jeg orker å skrive. De neste dagene må min mor holde kroppen min oppe når jeg kaster opp, jeg har ingen krefter, ingen energi, og ingen får kontakt med meg. Sykepleieren nekter å gå hjem fra jobb, og familie kommer på besøk i tilfelle jeg skal dø. Legene står samlet rundt undersøkelsesbenken uten å vite hva de skal gjøre. Det tar to dager fra jeg merker at det begynner å snu til jeg har krefter til å gi beskjed om det til noen. Mine hemmelige tanker om at jeg kan døviser seg å ha hold i virkeligheten.

Som tenåring stilt opp mot en mulig død hadde jeg behov for å snakke med noen om det jeg fryktet. Jeg våget aldri å innlede slike samtaler selv. Det var best ikke å kjenne på følelsene. Og det var lett å holde dem på avstand når ingen spurte. Leger må ta ansvar for å undersøke pasienters følelser. Derfor må legeutdanningen sikre at leger har de nødvendige verktøyene for å bli kjent med pasienten, ikke bare pasientens sykdom.

Leger må ha menneskekunnskap som kan hjelpe dem å undre seg frem til en forståelse av personen i pasienten. Undringen må utforske hvordan pasienten opplever situasjonen og hvilke behov han har. Uten slik undringskompetanse vil legen redusere pasienten til symptomer, prøvesvar og medfølgende diagnosekoder. Jeg ble redusert til min sykdom og brukte mange år på å reise meg og utvikle evnen til å snakke om identitetsarrene og følelsene som ble skapt i meg gjennom sykdomstiden.

Å få innsikt i pasienters plager, bekymringer og følelser krever gode kommunikasjonsferdigheter, med evne til å være nysgjerrig, undrende og åpen for å lære av hver pasient hva som er viktig for akkurat denne personen. Skal fremtidens leger lære dette, må trening og tilbakemelding gjennomsyre studiet som en naturlig del av all klinisk praksis. Evnen til å merke at kommunikasjonen knirker, for deretter å justere dialogen, tar tid å utvikle og krever veiledning. Hver samtale er unik. Leger må evne å improvisere, 
for det særegne i situasjonen krever skreddersøm. Ved å kombineres lytteferdigheter med forståelse av egne og andres emosjoner vil leger kunne bevege seg fra å behandle sykdommer til å behandle mennesker.

\section{Pasientens premisser}

Operasjonen skulle gjøre alt bra, men nå sitter jeg på sykehuset igjen. Kirurgen ser på meg. Jeg føler ikke at han er så veldig interessert i det jeg har å si. Han forstår ikke at jeg føler meg verre og verre, til tross for at de har fjernet magesekken min. «Det skal ikke være slik nå», sier han. Vel, det er slik nå, tenker jeg. Men jeg har ikke krefter i meg til å ta kampen, få ham til å forstå en situasjon han ikke vil forstå. Legen er mer interessert $i$ å fortelle meg hvorfor jeg ikke burde ha det slik, enn å høre på hvordan jeg faktisk har det.

Denne legen evnet ikke å se meg, men behandlet meg for min sykdom, ikke mitt tap av livsfunksjoner. Legekulturen må ha pasientens mål og verdier som en del av rettesnoren for hva som utgjør et godt behandlingsmøte. Når leger primært søker andre legers anerkjennelse, fremfor å søke tilbakemelding fra den som behandles, får de aldri vite hva som kunne vært bedre. Da minimeres pasienters rolle og legers læring. I grunnutdanningen ser vi som studenter at pasienter deltar omtrent som gisler i undervisningen, som alibi for klinisk læring, mens det ureflektert formidles til studentene at kommunikasjon over hodet på pasientene er uproblematisk. Utdanningen må gi pasienter tydeligere roller slik at studentene lærer at pasientene ofte er de beste til å undervise i hva sykdom betyr og hvordan leger kan løse sine oppgaver.

Ved å søke råd fra legen som profesjonell sykdomsbehandler ga jeg ham min tillit.
Jeg gjorde meg avhengig, la meg i den andres hender. Tillit gir stor makt til hjelperen. Den makten må leger bruke til å styrke pasientene. Det forutsetter at leger er genuint pasientsentrerte, ikke selvsentrerte. Hvis feilfrihet og vellykkethet blir medisinstudentenes primære mål gjennom grunnutdanningen, kan legemakten bli et

\section{«Legers evne til å bruke makt riktig gjenspeiles i evnen til å stå i usik- kerhet»}

redskap for selvopphøyelse og forsvar. Da vil legen distansere seg fra pasienten når ting blir vanskelig, for å unngå den truende hjelpeløsheten. Dermed hindres samarbeidet mellom lege og pasient, og pasientens autonomi og evne til vekst og forsoning svekkes. Legers evne til å bruke makt riktig gjenspeiles i evnen til å stå i usikkerhet og være trygg i møte med egen feilbarlighet.

Fremdeles får medisinstudenter høre at de er «kremen av kremen». Slik skapes ubevisste forestillinger om legestanden som en elitegruppe hvor feilbarlighet er «feil» og derfor må skjules. Slik kan studiet bidra til narsissisme, men også til en fryktkultur og ensom fortvilelse $i$ en yrkesrolle hvor feil både er uunngåelige og i særlig grad skjebnesvangre.

\section{Etterspill}

Et nytt forsøk på livet. Min første dag tilbake på skolen, den første dagen i det som forhåp- entligvis er en ny start. Jeg er bare to år forsinket, selv om jeg knapt har vært på skolen på fem år. På turen sitter jeg oppreist, uten å måtte skjule oppkast. Jeg er heldig som er i live, og takknemlig for helsepersonellet som har hjulpet meg på veien - fra vaskedamen som tøyset og holdt humøret mitt oppe, til legene og sykepleierne som har ligget våkne om nettene uten å gi opp håpet om å få meg frisk. Hvordan vil erfaringene, tankene som har slått rot i meg som sannheter, prege livet mitt? Vil jeg noensinne klare å legge det helt bak meg? I dag er jeg bare glad. Jeg skal få meg venner igjen, ha noen å være sammen med, slippe à være ensom.

Jeg takker Edvin Schei for uvurderlig veiledning ved utforming av denne teksten.

\section{Eivind A. Valestrand}

eivind.valestrand@gmail.com

Eivind A. Valestrand (f. 1989) er medisin- og forskerlinjestudent, 5. studieår, ved Universitetet i Bergen. Han har hatt flere sentrale tillitsverv for medisinstudenter både lokalt og nasjonalt. Fra 13- til 18-årsalderen var han alvorlig syk med lammet magesekk.

Forfatter har fylt ut ICMJE-skjemaet og oppgir ingen interessekonflikter.

Mottatt 28.2. 2016, første revisjon innsendt 6.3. 2016, godkjent 9.3. 2016. Redaktør: Ketil Slagstad.

> Se også intervju side 908. 